the more remote villages and districts the matrons had earned an honest penny by attending each other in their confinements, very much as the inhabitants eked out their livelihood by taking in each other's washing. As a result, obstetric disasters had been common, and in 1726 the Incorporation of Chirurgeons of Edinburgh had decided that an organized effort to train women for the office of midwives should be made without delay. An important minute of the Town Council of Edinburgh, dated February 9th, 1726, effected the foundation of the first chair of midwifery in the world. The minute ran as follows:

"The Council having considered the petition of $\mathrm{Mr}$. Joseph Gibson, chirurgeon in Edinburgh, with a declaration under the hands of four doctors of medicine, setting forth the usefulness and necessity of instituting a profession of midwifery; as also an extract of an act of the Incorporation of Chirurgeons, shewing their approbation of the qualifications and capacity of Joseph Gibson, one of their number, for teaching the said art and science; they were fully convinced that it would be of great use and advantage to institute this profession; and being well satisfied with the ability and capacity of the said Joseph Gibson to discharge that office, they were of opinion that the Counci should nominate and appoint him to be Professor of Midwifery in this city and privileges, with power to him to profess and teach the said art, in as large an extent as it is taught in any city or place where this profession is already instituted; and that he should be vested with the same privileges and immunities that are known to appertain to a professor of midwifery in any other wellregulated city or place; but that it should be expressly provided that he should have no fee or salary from this city out of its patrimony or revenue on account of his said profession. And having likewise considered that many fatal consequences have happened to women in childbirth and to their children through the ignorance and unskilfulness of midwives in this country and city, who enter upon that difficult sphere at their own hand, without the least trial taken of their knowledge of the principles upon which they are to practise that art, and that it would be a good service done to the community to put a stop to such practice, in order to prevent such mischiefs in time coming; they were of opinion that it should be enacted by the Council that no person hereafter should presume to enter on the practice of midwifery within this city and privileges till once they present to the magistrates a certificate under the hands of at least one doctor and one surgeon, who are at the time members of the College of Physicians or Incorporation of Chirurgeons of this city, bearing that they have so much of the knowledge of the grounds and principles of this art as warrants their entering upon the practice of it. ..."

The City Fathers had not realized what an original step they were taking, for there were, as a matter of fact, no other such appointments in existence. The duties of Joseph Gibson, tho first professor of midwifery, had been the teaching, not of medical students, but midwives, thus showing that the practice of midwifery was still at that date predominantly in the hands of midwives. Some thirty years after the foundation of the chair, Professor Thomas Young had given an unofficial course of midwifery for medical students concurrently with the instruction of midwives. He had also been the first to institute clinical teaching of obstetrics in Edinburgh, and he was permitted, at his own expense, by the managers of the infirmary, to fit up an attic room for four lying-in women or as many more as he could accommodate. This had been the origin of what ultimately, after many vicissitudes, developed into the Royal Maternity Hospital, erected in memory of Sir James Simpson. England had lagged far behind Scotland and tho Continent, so that it could not boast a university professorship of midwifery, and, what was still more startling, until the Medical Act of 1866 it was unnecessary for the medical student to be qualified in midwifery before being registered as a practitioner. Gynaecology, as a separate branch of surgery, had been non-existent until about the time of Sir James Young Simpson, the sixth and most distinguished occupant of the Edinburgh chair. In 1809, however, thirty years before Simpson was appointed, an epoch-making operation had taken place in the backwoods of Kentucky. Edinburgh had a special godmotherly interest in it inasmuch as Ephraim McDowell, who performed this first ovariotomy, had studied at Edinburgh, and had been profoundly inspired while a student in this city by the great John Bell, who was then one of the most eminent surgeons of the day.
Pioneers of Modern Times.

The additional factors which had been necessary to promote the growth of surgery and gynaecology to their modern dimensions had ieen provided respectively by $\mathrm{Sir}^{\circ}$ James Simpson when he discovered the anaesthetic properties of chloroform in his dining-room at 52, Queen Street, and by Pasteur and Lister in the discovery of bacteria and of tho antiseptic method for combating their evil effects in surgery. A profoundly important step had been the discovery of the fact that what was known as puerperal fever was the same as the condition called surgical fever-namely, a condition of bacterial infection occurring in wounded tissues. Many names, such as those of Charles White of Manchester, Gordon of Aberdeen, and Oliver Wendell Holmes, had been associated with the idea of infectivity in puerperal fever, but its nature had been discovered and brought prominently before the notice of the profession by a Hungarian, Semmelweiss, whose work had been supplemented by the discoveries of Pasteur and Lister. The lecturer referred to the activity in the chair of Sir Alexander Simpson, nephew of Sir James Simpson, and to Matthews Duncan, Milne Murray, and others of the Edinburgh obstetric school. With regard to Sir Halliday Croom, he said that no one he had ever known had shown such inspiring devotion to the teaching of his students. He mentioned especially the work of the late Dr. John William Ballantyne, who had been lecturer in midwifery to women students during Halliday Croom's tenure of the chair. Ballantyne had not been gifted with the talents which made a successful practitioner, but he had been endowed with what was more rare, the vision of the pioneer. He had founded what was practically a new branch of pathology-namely, ante-natal pathology-and for many years he had ploughed his lonely furrow through the arid wastes of this mest obscure and difficult subject. Ultimately it had been given to him to recognize what might now be said to be obvious, but what perhaps for that very reason had not been observed until he pointed it out-namely, the possibility of preventing many of the accidents and complications of labour and of the diseases complicating pregnancy. He had been one of the small band who definitely started the new development of antenatal supervision and thereby widened the whole conception of midwifery. Nowadays the ante-natal department was one of the most important parts of every maternity hospital, and there was no phase of obstetrics which had been more frutful in good results in the preservation of both maternal and infant life. As a prophet, Ballantyne had been favoured by being allowed to advance some little distance into the promised land which his vision had described. But death claimed him while as yet the full fruits of his labours were still to come. It was a particular satisfaction that their own Royal Maternity Hospital, which was erected to the memory of Sir James Simpson, in gratitude for the immortal contribution which he had made to medical and obstetrical science, should now have, as a complementary part, a Ballantyne Memorial in an ante-natal department, which might confidently be stated to be second to rone in the United Kingdom.

\section{THE FREEDOM OF MEDICINE.}

Introductory Address at the University of Durham College of Medicine, Newcastle-on-Tyne.

\section{O. HAWTHORNE, M.D., F.R.C.P., F.R.F.P.S. [Abridged.]}

Whuteven be the several stages you as individuals have reached in the undergraduate world, it is for all a common experience that your school days have ended; that you have entered as undergraduates in the life of a university; and that you are looking forward to the day when lecturers and examiners shall cease from troubling and, as you fondly imagine, weary graduates shall be at rest. Each of these three stages has, of course, certain features peculiar to itself, bit, broadly speaking, it may be said that as you pass from one to the next you move into a widening area of personal freedom." You have now definitely reached the second stage. 
Freedom in Undergraduate Life.

It is the youth who learns to obey that is the father of the man who is able to command. At the present moment you as medical students stand midway between these two terms. With the termination of school discipline you have stepped into the larger freedom of the undergraduate. Possibly, even yet, you may sometimes be more conscious of limitations than of liberties, and may complain of the irksome restraint of compulsory lectures and compulsory examinations. Nevertheless, the unirersity gives vou a wider freedom than the school, and this is true both of conduct and of opinion. The apprentice may now, as he will, be either industrious or idle, and this perhaps without any immediate reward or penalty, though sooner or later chickens come home to roost and acts carry their ineritable consequences. In the field of opinion, or at least in the expression of opinion, the undergraduate admittedly suffers some measure of restriction, more particularly in his contacts with examiners. The advantage of the last word in most questions rests with posterity; but this is not true of examinations. All the same, the atmosphere and influence of university life are towards the cultivation of a growing independence of judgement, the development of original views, and the assertion of personality. Especially valuable as educational agencies in these directions are the generous rivalries and loyal comradeships that you share with your fellows, the academic traditions that you inherit in common, and the activities and opportunities of your students' debating societies. In open controverss and criticism you are stimulated to think for yourselves, to advance arguments of your own, to contest the arguments of your fellows, and to cultivate ideas and the capacity of putting these into appealing and intelligible speech. The controversies may be fierce and the soft answer that turneth away wrath exceptional, but even in these asperities there is a training in the courtesies and proprieties of debate.

In short, the apparatus of a university has this purpose or end, to provide such a measure of freedom and such a degree of discipline that those who submit themselves to these opportunities shall be fitted for a still larger freedom and for a corresponding burden of responsibility. This ambition is not exhausted by mere technical efficiency, valuable and important as such efficiency necessarily is To it must be added, by the deliberate cultivation of the faculties of observation and judgement, and by the voluntary practice of self-discipline, the development of a mental habit and outlook which applies its estimate of values to all departments of life. A university education is effected not merely, perhaps not mainly, by didactic instruction. Not less important is the agency which leaves the student a measure of freedom within which he may train himself and be trained by his fellows, and this in an atmosphere rich in the traditions of the past and keen with the questionings and the uncertainties of the present hour. My suggestion, therefore, is that in your university life, while there is still direction to which you must needs attend, and a series of tests to which you must needs submit, there is also an opportunity to train yourselves to use freedom both wisely and well, and thus to prove yourselves competent for a still larger liberty. More than ever before, your fates are in your own keeping, for the liberties you now enjoy as students of medicine and university graduates may be made, if you so will, an educational apparatus by which you may add to technical efficiency in your profession the virtues and advantages of the trained, the equal, and the philosophic mind.

\section{Freedom in the Practice of Medicine.}

And now, what is the larger freedom for which you are preparing? In what sense, and in what degree, will you enjoy individual freedom within the scope and function of medical practice? There is here, of course, a question of opinion and a question of action; and the proposition I wish to set up is that in both of these respects the medical practitioner is a free man. There are qualifications in fact, and to these $I$ will allude in a moment, but in principle it is true, and we ought to be urgent to maintain it, that medicine offers a life where the individual judgement, the individual opinion, and the individual decision, are neither enforced on the one hand, nor restrained on the other, by an arbitrary, or quasi-infallible, or executive authority. There is no voice to which you must needs give heed that can inscribe on tables of stone a series of medical commandments, or that can compel vour subscription to thirty-nine or some other number of articles. Whether for good or for ill, the life offered by medicine is a life of intellectual liberty where every honest man may hold his own convictions, and express his own judgements, and follow his own policy; and this without fear either of authoritative censure or of official excommunication. However dignified and commanding certain professional organizations may be, none of them has the skill or competence to discharge thunderbolts against the practitioner who chooses to exercise his right of private judgement.

Now while this claim may confidently be made to-day, medicine is not without experience of a very different order. For centuries there was no liberty in medicine. On the contrary, there was a fixed and rigid orthodoxy from which any venturesome heretic dissented at his peril. Very substantial penalties fell on any innovator who ventured to question the medical scripture according to Galen as this was written in the second century of the Christian era. The doctors, in short, like the theologians, had a fixed and authorized code of doctrine and practice, and, again like the theologians, they were ready to "prove their doctrines orthodox by apostolic blows and knocks." But from this position, defined by authority, and from the sterile and stereotyped life and atmosphere which it produced, medicine has long since freed itself, though not without vigorous struggles and bitter controversies. To-day there are in medicine no orthodox opinions to which we must needs subscribe, and no compelling voice competent to define a creed or to enforce a method of practice. Over all this wide field it is for the individual to exercise his own judgement, to frame his own opinion, and to take his own decision. Such is the freedom, and, note also, such is the responsibility, to which you will be called.

\section{Restrictions on Liberty.}

It may, perhaps, be objected that this definition of individual freedom in medicine is an extravagant or exaggerated one. Can anyone reasonably say, it may be asked, that the individual medical practitioner is quite free from authoritative control, and is at full liberty to entertain any views that commend themselves to his judgement, and free also to apply these views in the conduct of his practice? The answer to these questions is decidedly in the affirmative, though this is not to say that such liberty ought to be exercised as a mere personal eccentricity, or as an expression of ignorant and obstinate selfwill. On the contrary, in this field as in others, a man must be prepared to defend his judgement by reasons and to justify his actions by results. He is free but he is responsible. There are certain limitations, it is true, but these are imposed by reason and logic and common sense, and not by any artificial bond or arbitrary authority. The limitations are in the nature of things. Thus, manifestly, a medical man is not free to poison a patient with opium or arsenic and then successfully to plead that in his opinion this proceeding was in the interests of the community; or, alternatively, that though he had indeed administered the poison, the responsibility for dying must be placed upon the patient. Neither in law nor in morals can ignorance, or stupidity, or carelessness, exhibited in a responsible situation, escape its due penalty by an attempt to take sanctuary under the protecting plea of the right of private judgement. The civil or criminal courts of the realm would make short work of such simplicity.

Again, beyond the bonds and limits of the law there are certain conditions which exercise a common-sense, or, if you will, a moral influence on medical liberty. It is true that there are in medicine no orthodoxies to which the faithful must needs adhere. On the other hand, there exist naturally and inevitably a number of doctrines and practices widely or almost universally accepted, and built on a more or less prolonged experience. A general consent of this order is a fact of much moment, and especially for the vounger members of the profession. What exists and seemis to have been tested by time and by many observers 
has surely a presumption in its favour. Beyond this admission, however, we must allow no restriction on liberty. No doctrine or practice in medicine, however ancient its lineage, however dignified its sponsor, or however favoured by the Fathers and Brethren, is or ought to be secure from critical or even destructive attack. The young practitioner may reasonably be expected to give some heed to the ancient ways, but the time may come when be refuses to walk therein and elects to challenge the accuracy or wisdom of the older guides. This is his heritage of freedom, and he can claim it without fear either of authoritative censure or of penal consequences.

Independence and Authority.

What I here claim, then, is that in medicine there is a free and open atmosphere for the man who has some new truth to teach, whether in the area of doctrine or in that of practice. Granted that he is of good faith, that his work is real and not pretence, and that he can give reasons for the faith that is in him, he will sooner or later command an audience and disciples. He may perhaps flutter the senior dovecots, not wholly to their disadvantage, for it is the duty, perhaps not always fulfilled, of those of us who feel in greater or less degree the chilling and numbing effects of years to keep an open mind, and indeed, an attitude of encouragement towards the independent enterprises of the younger, and, it may be, the wiser generation. There is no halfway house. Either men must bo free to think and speak the thing they will, uncomfortable as this may be for established opinion, or they must be liable to control or suppression by authority. Medicine has had its experience of this latter discipline, and has definitely abandoned it as antagonistic, not merely to freedom, but also to truth. If your desire is for a life of mental calm, where "all things always seem the same"; or if you wish a path and conduct ever dictated by superior authority, you had better seek these soporific ambitions in some profession other than that of medicine. Do not indulge the vain hope that freedom and fixture may somehow be combined. But if, as I gather, your choice is for the open fields and the wide spaces of medicine, be not negligent of your heritage of freedom. It is well for you, even in early days, to recognize these liberties and to cultivate them, not merely with discretion but also with courage. Medicine does not desire disciples drilled to a mere mechanical response to the orders of the sergeant-major. On the contrary, individual initiative has here a full opportunity, and it is your duty and interest to take advantage of this position and to cultivate, as you may, independent thinking and personal originality.

To sum up my present point I would say: You are to succeed to a great heritage of freedom; in that freedom respect by all means the traditions of the elders; but let these neither overawe you nor dismay you, nor bind you to a mechanical and unthinking obedience. I add that the attainment of this personal capacity is not achieved except by unrelenting effort: he who would see with his own eyes must learn to look without the use of other people's spectacles. In medicine you have this freedom if you care to use it. Ill would it become me to preach from this place a revolt against constituted authorities. Within limits we must all submit. But let it be remembered that originality of view and independence of judgement are qualities which, apart from their interest to the individual who possesses them, have a high value to the community and to the race. There is a large field of opportunity for them in medicine.

\section{Freedom of Opinion.}

The claim, then, is for freedom of opinion. Let us be quite sure of the meaning of our terms. Opinion is a word in everybody's mouth, though often it means nothing more than a personal taste or prejudice or preference, or an echo from a printed page. Our friends and acquaintances for the most part have what they call their "opinions" on almost every topic. They may modestly confess that they know little or nothing about the subject, but they are more than ready to tell us what they think. Of these exercises the medical practitioner has indeed special experience. Now in medicine when we speak of "opinion" wo mean something precise. A medical or scientific opinion may be defined as a mental conviction resting upon an intelligible basis; it is a judgement, inference; or conclusion resulting from the consideration of evidence. This is the sense in which the practitioner forms and acts upon his opinion in any individual case, or in which he gives his assent to any general medical proposition. Hence, when we say that in medicine there is liberty of opinion, we mean a rational and ordered liberty, exercised not on mere inclination or whim or fancy, but exercised in accordance with the logic and teaching of evidence. Observe that this statement does not justify an opinion on the ground of its accuracy. So long as men are fallible they will make mistekes, due perhaps to incomplete knowledge, perhaps to inaccurate information, perhaps to imperfect reasoning. An opinion in the sense here defined is not always right, but it is reached by an orderly and reasonable route, and if it proves to be inaccurate the localization of the flaw can be determined when all the facts are known. On the other hand, a mere guess may be right, and this, indeed, is one of its particular dangers, for the arrival of the lucky chance is apt to lead the author of the guess, whether he professes a diagnosis or backs a winner, to imagine himself a very smart fellow, forgetful of the truth that "winning tricks is not always proof of good play."

But with these irregular and illogical methods we are not concermed when we set up a plea for liberty of opinion within the province of medicine. What we mean by such liberty is the right of any practitioner, unhindered by authority, to scrutinize and cross-examine any proposition, to collect his own evidence, to form his own conclusions, and to push these if he will against current doctrines and practices. Truth unfettered, and spelt with a capital $T$, is the sole aim of medical inquiry, whether this is directed to an individual clinical problem or to a wide and general proposition. The lawyer seeks for truth according to a pre-determined standard and after having decided in advance what shall, and what shall not, be accepted as evidence, while for the ecclesiastic truth is already known, and the formal statements of it must neither be questioned nor challenged. But the doctor knows no such restrictions. He has to suffer much. uncertainty and doubt, and is continually aware how scanty is his knowledge and how limited are his powers. On the other side of the account he has this advantage, that he is never under an obligation to pretend to know what he knows he does not know, or to profess a conclusion on inadequate evidence. I am not questioning the advantage, or even the necessity, in certain spheres of life of the closing of issues by a final and con usive voice to which all must give attention. But in medicine there is neither a House of Lords nor a College of Cardinals, and it would be an ill day for medical science and medical practitioners, and for the general public, were any such organization called into existence.

Such, then, is the liberty to which you will be elected. It is not a riotous and tumultuous liberty. But it is a full liberty for honest work and for honest men. Admittedly it may be abused, and indeed few ambitions are easier than to be a successful medical humbug. Medicine offers two large opportunities-the opportunity to observe and to work, and the opportunity to pretend and to prance and to pose, this latter not without its rewards in the limelight. If the worker is to have the freedom that he needs, we must take our chance of the shams and simpletons. The good grain must be free to grow even though this means an opening for occasional tares. The claim therefore is, not that liberty carries no risks, but that it exists for those who have the courage to use it.

Opinion and Action: The Human Factor.

Perhaps it may be suggested that in a life where there is much liberty of prophesying, and where you may often be called upon to revise your conclusions and convictions, there cannot be much mental comfort. That is a perfectly fair comment, and for those for whom "there is no joy but calm" a medical career offers no inviting retreat. On the other hand, the consciousness of imperfect knowledge and of ignorance is a stimulus to initiative and enterprise and endeavour, and is it not largely in the 
exercise of these activities that man gets in his life mental happiness and satisfaction? Again, there is roóm for the remark that to live among open questions and undecided issues is liable to weaken the power of decision and to paralyse the capacity for action. We must not deny that medicine is by no means free from issues on which a confident opinion in the present state of our knowledge is impossible. To halt between two conclusions is sometimes unavoidable, and when we don't know there is credit, and not discredit, in saying we don't know. But we must distinguish between academic reserve and practical action. The daily life of the doctor repeatedly presents situations in which decision and action are imperative, while a confident pathological interpretation of the facts is for the time being impossible. The doctor, in other words, has to meet emergencies which cannot await scientific discussion; his first charge (even more than the discovery of truth) is the welfare of his patient; and he may often have to act, and act strongly, on a mere balance of probabilities. Thus, while he learns that deliberate judgements and opinions must be based on considered evidence, he is taught equally that quick wits and resolve and courage and promit action are essential in the practical business of life.

One other influence may be mentioned as tempering the mental questionings and debates of the medical atmosphere. It is that the doctor does his work not solely under the inflience of the cold, dry light of scientific knowledge. Associated with this throughout is a consciousness of the mystery of pain and suffering and of the sense of tears in human affairs. There is a scientific problem to be contemplated at the bedside, and this has to be solved in accordance with the strict demands of evidence. But there is something more-the welfare, and even the fate, of one with whom we are conscious we share in greater or less degree a common lot. Human emotions and sympathies and hopes and fears and sufferings and endurance are facts not less certain than the branches of the femoral artery or the percussion limits of cardiac dullness, and the doctor has to study and weigh these agencies if he would be not merely a student of disease but also the stay and succour of the patient. While strict accuracy in observation and record are one influence in his life, not less real is the discipline which inculcates understanding and sympathy and helpfulness. Thus while the practitioner of medicine may, and indeed often must, in his quiet study dwell in the realm of philosophic doubt, equally in his active service he is stimulated to prove himself the prompt, the informed, and the sympathetic helper of those who in their sufferings and distress turn to him with confidence and hope.

What is the conclusion of the whole matter? That in the life offered by medicine there is freedom for honest work and honest thought; that this freedom necessarily implies a corresponding measure of personal responsibility; and that any undue tendency to mere academic debate is corrected by the demands of practical affairs and by the appeal and mystery of pain and the hazards of human life.

\section{RELATIONS OF MEDICINE AND DENTISTRY.}

\section{SIR HUMPHRY ROLLESTON'S ADDRESS AT THE ROYAL DENTAL HOSPITAL.}

Ar the Royal Dental Hospital of London School of Dental Surgery the scholarships, prizes, and certificates awarded during the winter and summer sessions, 1925-26, were distributed on October 4th by Sir Humphry Rolleston, Bart., K.C.B., Regius Professor of Physic in the University of Cambridge, who gave an address on the relations of medicine and dentistry.

Both medicine and dentistry, he said, had travelled far on their own lines cluring the last forty years, and had got into rather closer touch on their journey; but in the interests of each more intimate association was desirable. Not so long ago the bearing of dental disease and dental deficiencies on gencral medicine was regarded as mainly concerned with referred pain, dental headache, and the mechanical factor-namely, incomplete mastication and the consequent swallowing of hard lumps of food. A great change was effected by the recognition of the etiological importance of dental sepsis in systemic disease. This advance was in the first instance the outcome of the patient investigations into the pathology of pernicious anaemia by William Hunter, who, in 1900 , described oral sepsis; out of this grew the more expanded conception of focal infection, and its importance was certainly not underestimated now. The employment of $x$ rays in examination of the teeth for apical disease had shown the close association of these lesions with rheumatoid arthritis, fibrositis, and allied conditions, which annually cost the nation three million weeks of lost work among the insured population. Not only had dental science done much for practical medicine, but advances in medical knowledge had thrown light on the causation of dental disease.

Correlation of Dentistry and General Medicine.

Dentistry and its followers had a tendency, much more marked than in other branches of the healing art, to be isolated from general medicine and surgery. To some extent this might be excused by the contention that theoretically dentistry should be a prophylactic science and art, and if carried out in a perfect manner should prevent any medical or surgical complications. But it would be very long before this ideal could be realized, and its advent would be facilitated by a more intimate association with general medicine and surgery. While the dental outpatient departments of general hospitals nominally formed a connecting link, in ordinary hospitals they were almost purely treatment, not teaching, departments; and though the patients, of course, benefited, there had been little gain to the advancement of dental science and.education. That there was a demand for dental schools in connexion with the general teaching hospitals had been proved by the success of the schools founded within the last forty years.

There were indeed good reasons for the close association of dental with medical schools. From the patient's point of view there was much to be gained by consultation, especially in cases on the border-line between dental and general medicine and surgery. The arrangements for treatment should be more. intimately united. Beds should be provided for patients undergoing extensive extractions and operations on the jaws which might come within the province of the general surgeon, and could not be dealt with satisfactorily in the out-patient department; while patients suffering from complications requiring medical supervision should obviously be under the care of hospital physicians. The need for beds for dental patients had now been recognized by the Middlesex Hospital in the allotment of beds to its dental staff. In the interests of dental science dentistry must gain by correlation with other departments, and by the application of new knowledge primarily derived from workers in different lines of research, but nevertheless of far-reaching practical importance. Contact with physicians, surgeons, pathologists, bacteriologists, and biochemists should enable combined researches to be made into the influence of general disorders, such as those of infective, metabolic, deficiency, and endocrine origin, upon the teeth. Conversely there was still much to be done in critical investigation and accurate evaluation of the influence of dental disease and defects on the body as a whole. The Dental Board encouraged research and had recognized the principle of increasing the opportunities for correlation of dental with other branches of medical investigation by arranging for lectures on general anaesthesia during the past year. From the point of view of dental students, the opportunities of seeing the medical and surgical complications of dental disease and of becoming familiar with the general disorders which might cause dental changes were obviously provided in a general teaching hospital.

\section{Medical Qualifications for Dentists.}

In other special branches of the healing art a good general knowledge of medicine and surgery, as shown by a qualification to practise, was a sine qua non. This was not held to be necessary in dentistry, and such a change might appear revolutionary. Revolutions, however, were often salutary, and were then called reforms. But a compulsory medical qualification for all dentists, however 